\title{
Building Eco-Cities of the Future: The Example of Masdar City
}

\author{
T. Mezher ${ }^{* a}$, G. Dawelbait ${ }^{a}$, I, Tsai $^{a}$, N. Al-Hosany ${ }^{b}$ \\ ${ }^{a}$ Masdar Institute of Science and Technology, iSmart Center, Abu Dhabi, UAE \\ ${ }^{b}$ Masdar Company, Abu Dhabi, UAE
}

\begin{abstract}
Global warming and increased population growth are putting more pressure on policy decision makers to adapt more sustainable approach to planning and designing future cities. This has led to the rise of Eco-Cities that have smart and sustainable infrastructures such as green buildings; intelligent transportation systems; and efficient electricity, water, wastewater, and solid waste networks. In addition these cities should be less dependent on fossil fuels and ensure healthier life and comfort. This paper gives a brief overview on the sustainable design concept of six Eco-cities from around the world such as Vauban in Germany, BedZed in the UK, Sonoma Mountain in California, Dongtan and Tianjin in China, and Sondgo in Korea. Masdar City is discussed in more details including the green buildings, intelligent transportation systems, and other important infrastructure systems. This endeavor requires the managing of complex systems which necessitates the coordination and collaboration of all the stakeholders that are involved designing, constructing, and operating the city. The paper concludes with lessons learned so far from Masdar City.
\end{abstract}

Keywords: Eco-City, Masdar, sustainable Abu Dhabi

\section{Introduction}

Global warming and increased population growth are the biggest challenges facing policy makers when it comes to planning future cities or improve existing ones. Modern urban areas are based on intergraded complex infrastructure systems to ensure comfort and healthy environment to their residents. Infrastructure systems include electrical, water and waste water, transportation, and sewage networks. The challenge today is to design such systems to be more efficient and effective, and less dependent on fossil fuels. Therefore, renewable resources solutions should be integrated into these complex systems.

In recent years, we have seen the rise of Eco-cities to mitigate the impact of global warming specially in countries that have high ecological footprints. The United Arab Emirates (UAE) and the United States of America (USA) have by far the highest ecological footprints in the whole world [1]. The consequences of these high ecological footprints imply that if everyone in the world lived their life as residents of the UAE and the USA, it would take around 4.6 planets to support the global population needs. This outcome is due to their total dependence on fossil fuel and the extremely unsustainable way of living of its inhabitants [2]. In general, recent studies showed that most economically strong countries have the worst ecological footprints. Surprisingly, these countries also have the most unsatisfied populations in the planet according to the happy planet index which takes into account the human wellbeing and environmental impact of each country. Some exceptional examples of poor countries with a high life expectancy and lower footprint reflected a more satisfactory life quality showing that "Good life is possible without costing the earth" [3].

These results, as well as the drastic impact of decades of irresponsible use of unsustainable energy sources on the climate change, imposed greater challenges and pressures to find solutions to save the planet. These pressures led to global efforts to take measures to save the environment while preserving the well-being of the population. Several of these efforts, such as the Kyoto Protocol, were geared towards the reduction of $\mathrm{CO} 2$ emission. Moreover, many international agreements were also designed to support the introduction of sustainable energy policies and awareness rising among people and decision makers. Some effort went beyond that by introducing the concept of Eco-cities, where cities are either built from ground up or renovated using new sustainable standards and codes. Since the switch to sustainable living is a recent years, there are still many uncertainties that need to be addressed. This paper will strive to show the difference between sustainable and conventional cities, the cost associated with green buildings, and the benefits from living in Eco-cities.

The literature identified several components for achieving sustainability. These include green building, energy and waste management, sustainable transport, $\mathrm{CO} 2$ reduction techniques,

${ }^{*}$ Corresponding author. Tel.: +97128109160

E-mail: tmezher@masdar.ac.ae.

(C) 2016 International Association for Sharing Knowledge and Sustainability

DOI: $10.5383 /$ ijtee.12.01.001 
and support for economic viability. As a starting step towards a sustainable living goal, it is most obvious to start from buildings. Buildings have an enormous and continuously increasing impact on the environment. They use about $40 \%$ of the natural resources extracted in industrialized countries, consuming nearly $70 \%$ of electricity and $12 \%$ of potable water, and producing between $45 \%$ and $65 \%$ of the waste disposed in landfills, making them responsible for $30 \%$ of the overall greenhouse gases emissions [4]. The high cost premium is the main current barrier to invest in green practices. However, recent studies identified energy cost savings and economical and social benefits coming from productivity and health as measures that on the long run pay back the initial investments and even make profit [5]

The literature review conducted for this paper covers environmental, economical and social aspects of sustainable cities as well as their interrelationships. Furthermore, we will investigate the multiple methods used to derive values for most of the financial, environmental, and social benefits, some of which are tangible such as cost saving, and $\mathrm{CO} 2$ emissions reductions and some are intangible benefits such as employee productivity and inhabitant's health.

This paper will start by defining Eco-cities and the concepts of sustainable design including green buildings and intelligent transportation systems. Examples from six existing Eco-cities are highlighted. More detailed descriptions of Masdar City design concepts are discussed. Finally, managing complex systems and the need for coordination and collaboration between all stakeholders are emphasized to ensure successful completion of the city.

\section{Eco-Cities}

\subsection{Concepts of Sustainability and Eco-cities}

During the last few decades, scholars proposed numerous definitions of sustainability. Yet, there is almost no consensus among those definitions found in the sustainable development literature. The most widely known definition of sustainable development comes from the Brundtland Commission [6], which defines sustainable development as "development that meets the needs of the present without compromising the ability of future generations to meet their own needs." Since then the definition of sustainability has been evolving. Several definitions limit the criteria of sustainability to maintaining ecosystems and natural resources, while others additionally speak of economic viability, social wellbeing, equity, cultural, and spiritual needs. The concept of living within environmental constraints was introduced by Daly and Cob in [7], where they also define sustainable development as improving the quality of human life while living within the carrying capacity of supporting eco-systems. In $[8,9]$, the sustainability is defined as the overlap between the three dimensions: the simultaneous pursuit of economic prosperity, environmental quality, and social equity. A more accurate view of sustainability is that the economy exists within society, and both the economy and society are limited by their environment [8]. Currently, most of the well accepted sustainable development definitions by the community have to do with living within one's own ecological limits. It understands the interconnections among economy, society, and environment, and equitable distribution of resources and opportunities $[7,10]$.

Eco-cities development has emerged as a way to address sustainability issues in the context of cities [11]. The Eco-City Builders expanded upon the definition of the term initially to be focusing on "reshaping cities for the long-term health of human and natural systems" $[12,13]$. Therefore, a successful Eco-city takes into consideration the synergy and interdependence of environmental, economic, and social sustainability and their fundamental ability to support and strengthen each other in the city context. Developers of Ecocities need to put in place the foundations to enable choices across all aspects of living and working to be sustainable ones. These include energy efficient buildings, renewable energy, resource efficient infrastructure and proximity to employment and services [14]. Many Eco-cities has been materializing all around the world in places such as Abu Dhabi, UK, Germany, and China. Some are small projects, e.g., Vauban in Germany and BedZed in the UK, Sonoma Mountain in California and some are of grand scale, e.g., Masdar City in Abu Dhabi, Tianjin in China, and Sondgo in Korea.

\subsection{Guidelines for sustainable buildings in Eco-cities}

To ensure a successful sustainable development, construction and maintenance should follow one or more of the internationally accepted sustainable buildings codes and standards. The performance of the buildings can then be measured and assessed using sustainability indicators and sustainable buildings rating systems. In the following sections we will discuss the main steps of designing, constructing and rating of buildings that constitute Eco-cities.

\subsubsection{Sustainability indicators}

In general, the performance and design of any Eco-city can be measured using standard sustainability indicators. These indicators, which include construction and maintenance, efficient energy use, transport, waste management, government support for business services and infrastructure, and environmental qualities, are discussed in details in the literature [15-17]. Table 1 below we present a list of the main sustainability indicators and their respective measurements.

\subsubsection{Building energy efficiency code and standards}

Currently, housing construction, maintenance and energy efficiency is governed by one or more of the international standards for energy performance for buildings such as the American Society of Heating, Refrigerating and Air Conditioning Engineers (ASHRAE) $[18,19]$, the British Chartered Institution of Building Services Engineers (CiBSE) [20], the German Passivhaus and the Swiss Minergie [21,22]. The International Code Council (ICC) is a membership association that develops the International Energy Conservation Code, a model energy efficiency code as well as its dedication to building's safety and fire prevention [23]. In Masdar City, all buildings are designed to be energy efficient following a Masdar own best practice standards, the Masdar energy design guidelines (MED). MEGD [12] draws from and exceed the most challenging requirements set out by a number of the above mentioned international energy efficiency standards, with particular emphasis on ASHRAE 90.1 and Passivhaus envelope performance requirements. Table II shows a summary of all these codes and standards. Regarding rating systems for environmental sustainable buildings, guidelines have been developed around the world to provide a framework for the assessment of green buildings performance by awarding credits in different environmental areas such as energy efficiency, water efficiency, indoor environmental quality, sustainable building material use, waste management and transportation. These rating systems are listed in the Table 2 below. 
Table 1. Sustainability indicators

\begin{tabular}{|c|c|}
\hline Indicators & Measurements \\
\hline $\begin{array}{l}\text { Housing, } \\
\text { construction and } \\
\text { maintenance }\end{array}$ & $\begin{array}{ll} & \text { Embodied } \mathrm{CO} 2 / \mathrm{m}^{2} \text { per home } \\
\text { - } & \text { Embodied } \mathrm{CO} 2 \text { for all infrastructure work } \\
\text { - } & \text { Housing quality in } \mathrm{m}^{2} \text { per person }\end{array}$ \\
\hline $\begin{array}{l}\text { Home energy } \\
\text { consumption }\end{array}$ & $\begin{array}{l}\text { - Energy consumption in GWh per year. } \\
\text { - Number of energy production plants. } \\
\text { - Number of efficient appliances. } \\
\text { - Percentage of used renewable energy. } \\
\text { - Energy monitoring for consumption to help } \\
\text { with behavior change. }\end{array}$ \\
\hline Transport & $\begin{array}{l}\text { - CO2 emission from personal transport per } \\
\text { person per year. } \\
\text { - Miles travelled by private cars and use of public } \\
\text { transport. } \\
\text { - Number of cars registered within the town. } \\
\text { - Cost and convenience of public transport to car } \\
\text { use. } \\
\text { - Traffic safety measured with number of people } \\
\text { killed and injured per } 10,000 \text { inhabitants. } \\
\text { - Transportation of goods travelling in and out } \\
\text { per kg per capita. }\end{array}$ \\
\hline $\begin{array}{l}\text { Waste } \\
\text { management }\end{array}$ & $\begin{array}{l}\text { - Calculated with production in tones per } \\
\text { inhabitant per year. } \\
\text { - Percentage of recycling and landfills. }\end{array}$ \\
\hline $\begin{array}{l}\text { Government } \\
\text { support for } \\
\text { business services } \\
\text { and infrastructure }\end{array}$ & $\begin{array}{ll}\text { - } & \text { Education institutions } \\
\text { - } & \text { Commitment to climate change }\end{array}$ \\
\hline $\begin{array}{l}\text { Environmental } \\
\text { quality }\end{array}$ & $\begin{array}{l}\text { - Water quality. } \\
\text { - Water consumption measured per inhabitant in } \\
\text { liters per day, the percentage of ground water } \\
\text { supply in total water use, and connection to } \\
\text { swage system. } \\
\text { - Air quality is usually assessed for the long term } \\
\text { by measuring SO2 and STP and for the short } \\
\text { term by measuring O3, SO2 and TSP. } \\
\text { - Ecological footprint. } \\
\text { - Area of green spaces. } \\
\text { - Acoustic quality which is measured by } \\
\text { exposure to noise above } 65 \mathrm{~dB} \text { and above } 75 \\
\text { dB. }\end{array}$ \\
\hline
\end{tabular}

Table 2. Buildings sustainability rating system

\begin{tabular}{|l|l|l|l|l|}
\hline & $\begin{array}{l}\text { LEED } \\
{[24]}\end{array}$ & $\begin{array}{l}\text { BREEAM } \\
{[25]}\end{array}$ & $\begin{array}{l}\text { Green } \\
\text { Star [26] }\end{array}$ & $\begin{array}{l}\text { Estidama } \\
{[27]}\end{array}$ \\
\hline Location & USA & UK & Australia & $\begin{array}{l}\text { Abu } \\
\text { Dhabi }\end{array}$ \\
\hline $\begin{array}{l}\text { Rating } \\
\text { Criterion }\end{array}$ & $\begin{array}{l}\text { Energy } \\
\text { efficiency }\end{array}$ & $\begin{array}{l}\text { Energy } \\
\text { efficiency } \\
\text { Climate } \\
\text { Change }\end{array}$ & $\begin{array}{l}\text { Energy } \\
\text { efficiency } \\
\text { Climate } \\
\text { Change } \\
\text { Thermal } \\
\text { comfort }\end{array}$ & $\begin{array}{l}\text { Energy } \\
\text { efficiency } \\
\text { Safety }\end{array}$ \\
\hline
\end{tabular}

\section{Eco-City framework and Components of Sustainable design}

The focus of this paper is to gain a better understanding of EcoCities. Our aim is to provide a framework for their construction by performing a global survey on master planned city initiatives. In a recent survey done Eco-Cities around the global, 79 cities were identified that fit the description and they were divided in into three categories and variables: (i) type of eco-city development (new development; expansion of urban area; 'retro-fit' development); (ii) development phase (pilot/planning stage; under construction; implemented); and (iii) key implementation focus/mode (technological innovation, sustainability visions, urban expansion, civic empowerment) [28]. This paper we will only focus on cities that have a master plan that is finished or still under construction. We will discuss sustainable design and construction practices in an eco city context which also includes green buildings, sustainable transport and city design. These sustainable design and construction practices can help turn sustainability into savings in terms of economy, energy and the environment.

\subsection{Green building state of the art}

Green buildings are the main component for sustainable design. They are the practice of creating structures and using processes that are environmentally responsible and resourceefficient throughout a building's life-cycle from inception to design, construction, operation, maintenance, renovation and deconstruction. This practice expands and complements the classical building design concerns of economy, utility, durability, and comfort [29]. Some benefits, such as improving occupant health, comfort, productivity, reducing pollution and landfill waste are not easily quantified [30]. Never the less, some studies showed that green buildings have a relatively large impact of productivity and health gains which reflects the fact that the direct and indirect cost of employees is far larger than the cost of construction or energy. Consequently, even small changes in productivity and health translate into large financial benefits $[31,32,33]$.

\subsubsection{Green buildings Life-Cycle Savings (LCS)}

Besides the use of on-site renewable energy power generation, lifecycle savings in green buildings mainly come from energy, water and material efficiency. Some energy saving measures start during the construction stage, such as the use of efficient material, e.g. using super insulation, bricks, concrete, glass for windows and glazing level. Energy efficient windows can decrease heating costs up to $40 \%$ and cooling cost up to $32 \%$. Additionally, energy and lighting efficiency can result into up to $80 \%$ energy savings through implementing strategies to provide natural lighting, installing of high-efficiency lighting systems with advanced lighting controls and including motion sensors tied to dimmable lighting controls [33].

Water efficiency also plays an important role in the overall LCS of buildings and public use. For buildings, a reduction of $15 \%$ of total water demand is possible by using efficient appliances and plumbing incentive as well as a reduction of $20 \%$ in average total wastewater flow. As for public use, reducing water consumption could be achieved through efficient use of water for landscaping. LCS from waste reduction strategies such as reuse and recycling come from avoiding disposal costs as well as costs of landfill creation. Another source of LCS, comes via insurance benefits of green buildings and lower mortgage from banks to buy eco houses. These insurance benefits are due to the advanced safety measures and low energy bills leaving more money available to pay the mortgage [30].

\subsubsection{Green building effect on employee productivity and health}

Savings that comes from health and productivity will result in increased earnings, reduction in respiratory diseases, and higher employee retention made up $85 \%$ of total whole life cost savings in addition to savings in energy, water and waste making up the remaining 15\% [5]. Improving indoor air quality by increasing ventilation can improve productivity to an average up to $1-1.8 \%$ which is equal to about 5-7 minutes per working day [30]. Health can also be improved through reduction of indoor contamination level by the use of efficient 
and nontoxic building material, VOCs and avoiding smoke as well as reducing biological contamination from bacteria, molds, pollen and viruses [33]. For example, 16-37 million cases of colds and flu could be avoided by improving indoor environmental quality. Additionally, healthier environment can be provided to employees by allowing more natural views and plants as well as enhancing different lighting systems including day light. Exposure to daylight alone can provide productivity gains ranging from $3 \%$ up to $34 \%$, with a mean of $7.1 \%$ [34]. More productivity can be achieved by way of thermal comfort by improving temperature control which may increase productivity up to $1.2 \%$ [35]. Finally, today, many argues that energy and water efficiencies technologies are not the only path toward sustainability, architect and engineering should adapt a new paradigm of mutualistic sustainability where building in cities are part of the same natural system [36].

\subsection{Sustainable Intelligent transport}

Intelligent transport are anticipated to grow in the next 15 years and billions of dollars will be invested on it [37]. Inefficient transportation system usually has a negative impact on economical, social and environmental sustainability objectives. The level of traffic in urban areas is an important explanatory factor for urban environmental quality as traffic causes noise, bad odors and local air pollution [38]. The transport sector accounts for $26 \%$ of the global $\mathrm{CO} 2$ emission and that is due to its large dependence on fossil fuel. Transport is also one of the few industrial sectors where emissions are still growing. This highlights the need to provide safe and efficient mobility while respecting the environment. Due to these issues, there is an urgent need for taking measures to implement more sustainable solutions for the transport sector.

A sustainable transportation system is one that: allows the basic access needs of individuals and societies to be met safely and in a manner consistent with human and ecosystem health, and with equity within and between generations; is affordable, operates efficiently, offers choice of transport mode, and supports a vibrant economy; and limits emissions and waste within the planet's ability to absorb them, minimizes consumption of non-renewable resources, limits consumption of renewable resources to the sustainable yield level, reuses and recycles its components, and minimizes the use of land and the production of noise [39]. Among all the different means of transportation, car use and road freight are the main contributors to greenhouse gas emissions. It is predicted that by 2020 the freight transport will increase by $50 \%$ and passenger transport with $35 \%$ [40] .This highlights the urgency to provide safe and efficient mobility while respecting the environment. Recently, multiple policy approaches targeting these two sectors (cars and freight) has been taken to reduce transportrelated carbon emissions. These policies can generally be grouped under three categories namely, vehicle travel reduction, reducing vehicle fuel use or a mix of these two approaches [41].

To reduce car use in particular, which is by far the most popular mode of transportation due to several reasons mainly affordability, poor levels of fitness, and unfavorable weather. Some efforts were geared towards supporting a modal shift into more sustainable transportation modes. These include the use of public transport such as buses and trains but additionally, 'zero-carbon' walking and cycling are the best alternatives. A commonly used policy to encourage the use of public transport is either by introducing tax incentives on smaller environment friendly cars that uses alternative fuel sources or by offsetting the affordability of cars ownership. This can be achieved by introducing taxations on road building, road tolling, parking charges and raising fuel prices where a $10 \%$ increase in fuel prices usually results in a 1-3\% decline in travel [42].

Another group of solutions is technological solutions such as improving engine efficiency and car design as well as intelligent software for route planning and technologies to reduce congestion. Another important issue of sustainable transport is the proper land use which usually does not favor automobile oriented development. Land use policies help reduce the need to travel (for example, by locating more stores and schools in residential neighborhoods) and increasing travel options [43].

Another policy direction is the development of alternative fuels and vehicles. Those include biofuels, gaseous fuel, hydrogen fuel cell electric vehicles, and battery powered electric vehicles and hybrid electric vehicles. When comparing the different policies to achieve sustainable transport, it has been found that although more efficient vehicles and alternative fuels help conserve energy and reduce air pollution, it fails to satisfy other sustainability objectives such as congestion reduction, traffic safety and increased public fitness and health, and land use sprawl, or improved opportunity for disadvantaged people. Vehicle travel reduction strategies help achieve more objectives and are considered more sustainable [40].

The main objectives and benefits of sustainable intelligent transport have been identified in the literature to be: safety; carbon reduction; convenience through sufficient number of vehicles, frequency of stations, and minimum waiting times; mobility; efficiency; cost saving; and energy/environmental and consumer satisfaction. New and emerging technologies, and infrastructure changes in the cities around the world include the use of Personal Rapid Transit (PRT), Bus Rapid Transit (BRT), and public share bikes and cars [44].

The use of Personal Rapid Transit (PRT) system showed a benefit of around a factor of two over the best trip times achievable by conventional corridor transport [45]. PRTs are currently being used in Masdar City, United Arab Emirates (UAE). The Bus Rapid Transit (BRT) corridors are exceedingly becoming a user friendly mode of transport to cover the branches in the city. In Istanbul, the in-vehicle travel time has been reduced by $50 \%$ and since the bus pathways are separated from the motorways, the speed and time is almost always a constant, thus aiding in quick movement to the points in the branches of the city centre. The buses can work on $15 \mathrm{~km} / \mathrm{hr}$ speed. The Tindo solar electric bus is one example of BRTs [46].

Public share bikes and cars are mainly used to cover the last mile or the sub-roots of the city transportation infrastructure. Every entity of the city would have kiosks or "sharing stands". Each would have a solar panel which would act as the recharging centers for these vehicles which would run on solar. To aid easy access to these vehicles, an online database would be provided about the bike trails and also car sharing and availability of the vehicles. Every person would be given a smart card which would be swiped in the kiosk machines and the vehicles can be accessed. As soon as the work is done, it would be deposited to the kiosk of the destination station. Since, there would be mobility to and from a place; the availability of vehicles would not be an issue. This could specifically be used in the sub-branch entity of the city or can cover internal entities like universities, hospitals, intermodal shifts like from the PRT to BRT bus stations. In these systems Information technology plays a very important part in aiding the process of "efficiency", "user-friendliness" and 
"manageability". The system architecture should include intelligent communication and tracking systems to provide vehicle location and identification. Dispatching and reservation systems to obtain information about check out and out-bound vehicles and a smart card technology to aid vehicle access control. For car sharing an on-board navigation and travel information should be provided to assist users operating within a shared vehicle system [47].

\section{Existing Eco-cities}

The main objective of Eco- cities is to demonstrate real and measurable sustainable living and encourage people to live within ecological limits whilst enjoying a high quality of life. In this section, we mention some existing Eco-cities that have gone through the sustainable experience. The lessons learned from these experiences would help us understand successful and unsuccessful efforts of building Eco-cities, it also ensures that time-tested principles are acknowledged and used where appropriate. Six Eco-cities are listed for reference, three of small scale, i.e., BedZED [48], Vauban (Freiberg) [49] and Sonoma [50], and three of big scale, i.e., Dongtan [51], Tianjin [52], and Sondgo [53].

\section{Masdar city}

In April 2006, Abu Dhabi took a bold and historic decision to embrace renewable and sustainable energy technologies. Hence, the Masdar Initiative was created. The Masdar Initiative has four primary objectives: (1) to help drive the economic diversification of Abu Dhabi; (2) to maintain, and later expand, Abu Dhabi's position in evolving global energy markets; (3) to position the country as a developer of technology, and not simply an importer; and (4) to make a meaningful contribution towards sustainable human development. To implement the Masdar Initiative, Abu Dhabi government has created Masdar Company which currently has 5 units. The first unit is Masdar City which is overseeing the building of the city. The second unit is the Masdar Power which is responsible for building renewable energy power plants in and outside UAE. Masdar Institute of Science and Technology (MI) is the third unit and it is the first research oriented graduate university in the region dedicated to renewable energy and sustainability. The fourth unit is Masdar Capital which seeks to build a portfolio of the world's most promising renewable energy and clean technology companies. It helps its portfolio companies grow and scale-up by providing capital and management expertise. Masdar Capital targets investments that have the greatest potential globally and to the UAE and is particularly focused on sustainable related energy related sectors. The fifth unit is Masdar Carbon which manages projects that bring reductions in carbon emissions through energy efficiency and waste heat/CO2 recovery, as well as through carbon capture and storage (CCS) [54].

Masdar City is the world's first carbon-neutral and zero waste city. It is located at the heart of Abu Dhabi, the capital of the UAE. The main objectives Masdar City are to create a global clean technological hub, powered by renewable energy, worlds best sustainable urban development, low carbon foot prints, unmatched platform for commercial-scale demonstration of sustainable technologies, home to leading research institute in alternative energy and sustainable technologies and have partnerships of excellence. Masdar city is a good example of how future cities will be shaped. The city is inspired by the architecture and urban planning of traditional Arab cities. It incorporates narrow streets, the shading of windows, exterior walls and walkways, thick-walled buildings, courtyards and wind towers, vegetation, and a generally walkable city. Table 4 shows Masdar City facts [55].

Table 4. Masdar City Facts

\begin{tabular}{|l|l|}
\hline Total Site Area & 700 ha, 3.7M sqm GFA \\
\hline Residential & $52 \%$ \\
\hline Commercial & $38 \%$ \\
\hline Retail & $2 \%$ \\
\hline Community & $8 \%$ \\
\hline $\begin{array}{l}\text { Projected Resident } \\
\text { Population }\end{array}$ & 40,000 \\
\hline Projected Commuters & 50,000 \\
\hline Residential Density & 140 People/Hectare \\
\hline Peak Daily Density & 245 People/Hectare \\
\hline
\end{tabular}

Masdar City will be a test bed for new concepts to planning, designing, engineering, constructing and operating sustainable cities. Masdar City will set a benchmark that will ultimately support sustainable development throughout Abu Dhabi and the region, as well as provide a functioning blueprint for sustainable living around the world. The city embraces many of the One Planet Living (OPL) principles which go beyond normal urban sustainability steps that take into account all measures to ensure living can be achieved within the fair share of the earth's resources. Masdar City has three added values. The first one is economical which relates to real estate development, joint venture, intellectual property owner ship, and human capital development. The second is environmental which include net zero carbon, $100 \%$ renewable energy, intelligent transport, and green buildings. The third is the social benefit and better quality life from living in the city which is the results of the first two.

Table 5 shows the current sustainable achievements in Masdar city. The ultimate goal will be achieved when the city is completed by 2025 and by then there will be more technological breakthroughs in construction innovation and more knowledge will be created in building sustainable cities [55].

Table 5. Current Achievement in Masdar City

\begin{tabular}{|c|c|}
\hline Sustainability Goal & Achievements to date \\
\hline \multirow{2}{*}{$\begin{array}{l}\text { Energy Demand } \\
\text { Reduction }\end{array}$} & - $51 \%$ less energy in residential units \\
\hline & $\begin{array}{l}\text { - } 55 \% \text { reduction in building external heat } \\
\text { gain }\end{array}$ \\
\hline \multirow{3}{*}{ Renewable Energy } & $\begin{array}{l}\text { - Up to } 30 \% \text { of electricity provided by } \\
\text { 1MW rooftop solar PV }\end{array}$ \\
\hline & - Built 10MW solar PV farm \\
\hline & $\begin{array}{l}-75 \% \text { of hot water provided by rooftop } \\
\text { solar thermal collectors }\end{array}$ \\
\hline $\begin{array}{l}\text { Water Demand } \\
\text { Reduction }\end{array}$ & $\begin{array}{l}54 \% \text { less water consumption in residential } \\
\text { units }\end{array}$ \\
\hline $\begin{array}{l}\text { Waste Diverted from } \\
\text { Landfill }\end{array}$ & $\begin{array}{l}96 \% \text { of construction waste reused or } \\
\text { recycled }\end{array}$ \\
\hline $\begin{array}{l}\text { Reduction in Embodied } \\
\text { Carbon in Materials }\end{array}$ & $\begin{array}{l}\text { Used low-carbon aluminum and concrete } \\
\text { mixes in buildings, infrastructure }\end{array}$ \\
\hline $\begin{array}{l}\text { Intelligent Transport } \\
\text { System }\end{array}$ & $\begin{array}{l}\text { PRT already in use to transport } \\
\text { individuals from parking lot to Masdar } \\
\text { Institute }\end{array}$ \\
\hline
\end{tabular}




\subsection{Masdar City living principles}

The Masdar City living principles are inspired by OPL principles which go beyond normal urban sustainability measures to ensure living within our fair share of earth's resources [17]. To ensure meeting the stringent sustainability targets of the city, the performance during construction and after operation will be monitored by several principles, performance indicators, and sustainability targets that are very close to OPL principles and are summarized in Table 6 below [16].

Table 6. Masdar City principles, indicators and targets

\begin{tabular}{|c|c|c|}
\hline $\begin{array}{l}\text { Masdar } \\
\text { Principles }\end{array}$ & Indicators & Masdar targets \\
\hline Zero Carbon & $\begin{array}{l}\text { 1. Energy from } \\
\text { renewable sources } \\
\text { 2. Carbon released } \\
\text { during operation } \\
\text { 3. Energy efficient } \\
\text { buildings } \\
\text { 4. Embodied carbon of } \\
\text { construction }\end{array}$ & $\begin{array}{l}\text { 1. } 100 \% \text { on-site } \\
\text { renewable sources } \\
\text { 2. Net zero tones for } \\
\text { operation } \\
\text { 3. } 80 \% \text { reduction } \\
\text { compared to Abu Dhabi } \\
\text { 4. Offset through on- } \\
\text { sites renewable } \\
\text { generation }\end{array}$ \\
\hline Zero waste & $\begin{array}{l}\text { 1. Diversion from } \\
\text { landfill } \\
\text { 2. Waste minimization } \\
\text { 3. Recycling, waste to } \\
\text { energy, composting }\end{array}$ & $\begin{array}{l}\text { 1. } 99 \% \text { by } 2020 \\
\text { 2. } 30 \% \\
\text { 3. } 50 \%, 33 \%, 17 \%\end{array}$ \\
\hline $\begin{array}{l}\text { Sustainable } \\
\text { transport }\end{array}$ & $\begin{array}{l}\text { 1. } \mathrm{CO} 2 \text { emission due } \\
\text { to transport } \\
\text { 2. Journeys from and to } \\
\text { Masdar }\end{array}$ & $\begin{array}{l}\text { 1. } 0 \mathrm{kgCO} 2 / \text { year } \\
\text { 2. } 55 \% \text { by private cars } \\
\text { and } 45 \% \text { public } \\
\text { transport }\end{array}$ \\
\hline $\begin{array}{l}\text { Culture and } \\
\text { heritage }\end{array}$ & $\begin{array}{l}\text { 1. Preserving culture } \\
\text { and heritage through } \\
\text { building and city design }\end{array}$ & $\begin{array}{l}\text { 1. Narrow streets } \\
\text { inspired by traditional } \\
\text { Arabic architecture, use } \\
\text { of wind catchers for } \\
\text { passive ventilation }\end{array}$ \\
\hline $\begin{array}{l}\text { Equity and } \\
\text { fair trade }\end{array}$ & $\begin{array}{l}\text { 1.Fair wages and } \\
\text { working conditions } \\
\text { 2. Support of } \\
\text { disadvantaged groups }\end{array}$ & $\begin{array}{l}\text { 1. Fair wages for all } \\
\text { employees during } \\
\text { construction and } \\
\text { operation } \\
2 \text {. Identify target } \\
\text { projects and target for } \\
\text { increasing projects } \\
\text { capacity to } 100 \% \text { by } \\
\text { target group }\end{array}$ \\
\hline $\begin{array}{l}\text { Health and } \\
\text { happiness }\end{array}$ & $\begin{array}{l}\text { 1. Buildings design to } \\
\text { integrate health and } \\
\text { happiness principles } \\
\text { 2. Residence } \\
\text { satisfaction levels }\end{array}$ & $\begin{array}{l}\text { 1. Zero emission, } \\
\text { walking and cycling } \\
\text { lanes, maximum } \\
\text { daylight, avoid toxic } \\
\text { materials, minimize } \\
\text { noise pollution not to } \\
\text { exceed EAD guidelines } \\
\text { 2. } 70 \% \text { of residence } \\
\text { reporting better life } \\
\text { quality and each } \\
\text { residence knows } 15 \\
\text { neighbors by name }\end{array}$ \\
\hline
\end{tabular}

For most of the targets in Table VII, the consumption of the city of Abu Dhabi was used as the baseline, otherwise when information is not available, regional or international baselines have been used. One of the main focuses of the Masdar City is on sustainable buildings and that is due to their enormous and negatively increasing impact on the environment. Therefore, to provide a state of the art sustainable living environment, Masdar City follows the tailor made Masdar Energy Design Guideline (MEDG) for sustainable building standards. MEDG is generally stricter than other existing energy guidelines. It draws from most international building design standards in addition to extra standards that are specific to desert regions in general and to Abu Dhabi and Masdar City in particular [16]. The Masdar initiative plans to maximize the on-site energy generation via renewable energy sources. The use of renewables will lead to a carbon emission reduction of up to 98.8\% making Masdar the first carbon neutral city. The next sections introduce the different elements that make Masdar a sustainable city.

\subsection{Masdar City design concept}

The way the city is designed is to promote sustainable living. The city is located in the heart of Abu Dhabi on six square kilometers of land near the airport. This location has one of the highest solar radiations in the region ensuring full utilization of solar energy. Its proximity to Abu Dhabi makes commuting, and goods transportation to the city more economical and with minimum $\mathrm{CO} 2$ emission. The walled city is built using narrow streets for shading and using wind catchers for passive ventilation to ensure good outdoor air quality. It also provides walking and cycling lanes throughout the city for enjoying outdoors activities and more fitness.

\subsubsection{Green buildings}

One of the most evident human activities weighing on pollution and energy consumption is the construction of human residential buildings. Green buildings are usually designed in an ecological and resource-efficient manner. They are designed to meet certain objectives such as protecting occupant health; improving employee productivity; using energy, water, and other resources more efficiently; and reducing the overall impact to the environment. The benefits of green buildings include cost savings from reduced energy, water, and waste; lower operations and maintenance costs; and enhanced occupant productivity and health.

All buildings in Masdar City are designed to be energy efficient following a Masdar own best practice standards -The Masdar energy design guidelines (MEDG). The Masdar MEGD draws from a number of international standards for energy performance for buildings, e.g. LEED, BREEAM, Passivhaus, but will exceed the most challenging requirements set out in these building designs. The buildings forms and designs will integrate health and productivity of occupants through several measures starting with avoiding the use of toxic material such as Formaldehyde, volatile organic compounds as well as phthalates, e.g. PVC carpet, wall covering, ceiling tiles and wiring.

The Masdar City buildings will also provide natural daylight from courtyards and streets and solar control glazing with daylight transmission of more than $65 \%$. All materials shall meet the requirement of USGBC LEED-NC version 2.2 or later for indoor environmental quality [56]. The Masdar City target is to provide on-site $100 \%$ renewable energy. Furthermore, the green buildings in Masdar are also designed to reduce energy demand load for electricity and cooling by $70 \%$ compared to the Abu Dhabi baseline and that is by adjusting the following parameters as outlined in the Masdar Master plan: optimizing natural light, internal lighting, infiltration, ventilation, efficient appliances, controlled operation such as smart grid and peak load management. As for water efficiency, the Masdar plan is to reduce the water consumption from 350 (average house hold water consumption in Abu Dhabi) to 140 liters/person/day.

\subsubsection{Sustainable Intelligent Transportation in Masdar City}

According to the Masdar City Master plan, the only mean of transportation inside the city will be the PRT which is 
environmentally friendly, clean and less noisy. Also, it provides a level of service that is superior to that available from conventional public transport the vehicles travel along a network of guide ways, much like a network of streets the travel is point to point, with no intermediate stops or transfers. Personal rapid transport (PRT) will link all car parks located outside the city. The inner city will have a network consisting of 74 stations with a maximum walking distance of $150 \mathrm{~m}$ to each station the network will operate in an under croft ensuring safety and no congestion. All the vehicles will be powered by renewable energy produced inside Masdar City resulting in zero $\mathrm{CO} 2$ emission from transportation. Freight and waste and emergency services will use the same technology and network [16]. After the PRT has been used for more than year, Masdar City is now exploring the use of other sustainable transportation systems. The BRT system is one option as they become more users friendly and practical to enhance its intelligent transportation system around the city. In addition, upon the completion of the city, a public transport system of electric buses, electric cars, and other clean-energy vehicles will provide transport within the city, while Abu Dhabi's light rail and Metro lines will pass through the centre of Masdar City, providing transport within the city and serving as a link to the wider metropolitan area. Most private vehicles will be kept at the city's edge in parking lots that will be linked by public transportation to the rest of the city. Finally, Masdar City has initiated an electric car pilot with Mitsubishi Heavy Industries to test a point-to-point transportation solution for the city that uses Mitsubishi Motor's i-MiEV, five-door hatchbacks, which are power by renewable energy.

\section{Conclusion}

This paper gave an overall view on how sustainable cities of the future should be. This includes green buildings and intelligent transport systems. More detailed description of Masdar City was given including how to manage complex systems and the lessons learned so far. The development of Eco-cities requires high capital investment and the return on such investments is a long term one. Today, the economic hardship is putting pressure on existing Eco-city projects and many of them will be delayed for financial reasons. Funding for such Governments are In addition, it made many developers to rethink their original concept and designs to reduce their cost and generate returns faster for investors. Eco-cites should be competitive with traditional cities. All the stakeholders should be involving in all the phases of the designing, constructing, and operating the city. Energy efficiency and renewable energy technologies are moving targets, and Eco-cities must be careful in adopting them and should take into consideration the overall Life-Cycle cost of each phase of the city.

\section{Acknowledgment}

We would like to acknowledge the financial support of Masdar City and Masdar Institute of Science and Technology.

\section{References}

[1]. Global Footprint Network, The Ecological Footprint Atlas 2009. Oakland: Global Footprint Network, 2009.

[2]. World Wildlife Foundation, Living Planet Report 2008. Switzerland: WWF, 2008.

[3]. S. Abdallah, S. Thompson, J. Michaelson, N. Marks, and N. Steuer, The Happy Planet Index 2.0. London: New Economics Foundation, 2009.

[4]. D. Castro-Lacouture, J.A. Sefair, L. Flórez, and A.L. Medaglia, "Optimization model for the selection of materials using a LEED-based green building rating system in Colombia," Building and Environment, vol. 44, no. 6, pp. 1162-1170, 2009.

[5]. M.H. Issa, J.H. Rankin, and A.J. Christian, "Canadian practitioners' perception of research work investigating the cost premiums, long-term costs and health and productivity benefits of green buildings," Building and Environment, vol. 45, no. 7, pp. 1698-1711, 2011.

[6]. World Commission on Environment and Development (WCED), Our Common Future. Oxford University Press, 1987: p. 43.

[7]. H. Daly, and J. Cobb, For the Common Good: Redirecting the Economy toward Community, the Environment and a Sustainable Future. Beacon Press: Boston, MA, USA, 1989.

[8]. L. Lee, "Sustainability: Living within One's Own Ecological Means," Sustainability, vol. 1, pp. 14121430, 2009

[9]. W.M. Adams, "The future of sustainability: re-thinking environment and development in the twenty-first century," Report of the IUCN Renowned Thinkers Meeting, Gland, Switzerland, 29-31 January 2006.

[10].L. Todd, "Well Measured Developing Indicators for Comprehensive and Sustainable Transport Planning," Victoria Transport Policy Institute, 4 February 2011.

[11].H. May, "Sustainable Urban Development and Chinese Eco-City: Concepts, Strategies, Policies and Assessments." Fridtjof Nansen Institute (FNI) Report, 2009.

[12].R. Register, Ecocity Berkeley: Building Cities For a Healthy Future. Berkeley, California: North atlantic books, 1987.

[13].Ecocity Builders, Ecocity Builders: 2009/2010 Annual Report. Oakland, California: Ecocity Builders, 2010.

[14]. BioRegional and CABE, What makes an eco-town? A report from BioRegional and $\mathrm{CABE}$ inspired by the eco-towns challenge panel, Wallington, Surrey: BioRegional, 2008.

[15]. Australian Conservation Foundation, The Sustainable Cities Index. Melbourne: Australian Conservation Foundation, 2010.

[16].Masdar City, Masdar Energy Design Guidelines (MEGD) version 1.0 Offices and Residential, Abu Dhabi, UAE: Masdar, 2009.

[17].Bioregional, One Planet Vision: tools and inspiration to help you create a sustainable future, available from http://www.oneplanetvision.org, accessed August 2013.

[18]. The American Society of Heating, Refrigerating and Air-Conditioning Engineers (ASHRAE), available from: http://www.ashrae.org/, accessed August 2013.

[19].R. E. Jarnagin, M. McBride, C. Trueman, and R. J. Liesen, "Demand or no demand: electrical rates for Standard 90.1-2010.” ASHRAE Journal, April 2008.

[20]. About CiBSE, available from: $\mathrm{ttp}: / / \mathrm{www}$.cibse.org/index.cfm?go=page.view\&item $=37$ , accessed April 30, 2012.

[21].Passive House, available from: http://www.passivhaustagung.de/Passive_House_E/pass ivehouse_definition.html, accessed April 30, 2012.

[22].Minergie, available from: http://www.minergie.com/home_en.html, accessed April 30, 2012.

[23].International Code Council, available from: http://www.iccsafe.org/AboutICC/Pages/default.aspx, accessed April 30, 2012.

[24].United States Green Building Council (USGBC), an introduction to the United States green building council and the LEED green building rating system, Available 
from:

http://www.usgbc.org/DisplayPage.aspx?CMSPageID= 1970\#2, accessed August 8, 2013.

[25].BREEAM, Environmental Assessment Method for Buildings Around The World, available from: http://www.breeam.org/index.jsp, accessed August 8, 2013.

[26].Green Building Council Australia, Green Star. Available from: http://www.gbca.org.au/greenstar/green-star-overview/what-is-green-star/2139.htm, accessed April 30, 2012.

[27]. Urban Planning Council, Interm ESTIDAMA Community Guidelines: Assessment System for Commercial, Residential and Institutional Development, Internal Report, Abu Dhabi, UAE, August 2008.

[28].S. Joss, "Eco-cities — a global survey 2009," WIT Transactions on Ecology and The Environment, 129:239-250, 2010.

[29].U.S. Environmental Protection Agency, Green Building: Basic Information, available from http://www.epa.gov/greenbuilding/pubs/about.htm, accessed December 10, 2013.

[30].S. Cloutier, L. Larson, and J. Jambeck, "Are sustainable cities "happy" cities? Associations between sustainable development and human well-being in urban areas of the United States." Environ Dev Sustain 16:633-647, 2014.

[31].G. Kats, , L. Alevantis, A. Berman, E. Mills, J. Perlman, The Costs and Financial Benefits of Green Buildings, A Report to California's Sustainable Building Task Force, October 2003

[32]. W.J. Fisk, and A.H. Rosenfeld, "Estimates of Improved Productivity and Health from Better Indoor Environments." Indoor Air, 7:3, pp. 158-172, 1997.

[33].U.S. Environmental Protection Agency, Economic Benefits of Green Building Design, available from http://www.epa.gov/tribalcompliance/prevandpurch/ppe conomicdrill.html, accessed December 10, 2010.

[34].C.G., Steiner, Super Building Technology with Zero Green House Gases Emission to the Environment, available from http://www.altenergymag.com/emagazine.php?issue_nu mber $=06.12 .01 \&$ article $=$ supergreen, $\quad$ accessed December 10, 2013.

[35].G., Kats, Greening buildings and communities: costs and benefits, available from http://www.goodenergies.com/news/pdfs/Web\%20site\%20Presentation.pdf, accessed December 15, 2013.

[36]. E. Ozer, "Mutualistic relationships versus hyperefficienciesin the sustainable building and city," Urban Ecosyst 17:195-204, 2014.

[37]. A.K. Debnath, H.C. Chin, M.M. Haque, B. Yuen,”A methodological framework for benchmarking smart transport cities," Cities 37: 47-56, 2014.

[38].C. C. Federspiel, W. J. Fisk, P. N. Price, G. Liu, D. Faulkner, D. L. Dibartolomeo, D. P. Sullivan and M. Lahiff, "Worker performance and ventilation in a call center: analyses of work performance data for registered nurses," Indoor Air 14: 41-50, 2004.

[39].K. Geurs, and J. Adams, Economic and social impacts of sustainable transport, European Transport Conference Proceeding, 1999.
[40].D. Bannister, "Sustainable urban development and transport: A Eurovision for 2020." Transport Reviews 20:1:113-130, 2000.

[41].L.Chapman, "Transport and climate change: a review." Journal of Transport Geography 15:354-367, 2007.

[42].L. Fulton, Saving oil and reducing CO2 emission in transport: Options and strategies. Workshop on Good Practices in Policies and Measures, Copenhagen, 8-10 October 2001.

[43].J. Anable and B. Boardman, Transport and CO2. UKERC Working Paper, 2005. , available from: http://www.ukerc.ac.uk/support/tikidownload_file.php?fileId=252, accessed August 15 2012.

[44].T.Litman, and D. Burwell, "Issues in sustainable transportation," Int. J. Global Environmental Issues 6:4:331-347, 2006.

[45].M. Vanderschuren, "Safety improvements through Intelligent Transport Systems: A South African case study based on microscopic simulation modeling." Accident Analysis \& Prevention 40:2:807-817, 2008.

[46].M. Lowson, "Service Effectiveness of PRT vs. Collective - Corridor Transport." Journal of Advanced Transportation 37:3:231-341, 2003.

[47].TINDO. The world's first solar electric bus, available from: www.adelaidecouncil.com/tindo, accessed August 17, 2012.

[48].M. Barth, M. Todd, and S. Shaheen, "Examining Intelligent Transportation Technology Elements and Operational Methodologies for Shared-Use Vehicle Systems," Transportation Research Record, 1481, paper no. 03-4187, pp. 99- 108, 2003.

[49].BioRegional, BedZED Case Study, General Information Report 89, available from: http://www.bioregional.com/files/publications/BedZED BestPracticeReport_Mar02.pdf, accessed August 15, 2013.

[50].Intelligent Agency Europe. Vauban: A Benchmark Study, available from: http://www.secureproject.org/download/18.360a0d5611 7c51a2d30800078420/Vauban_Germany.pdf, accessed August 18, 2013.

[51].BioRegional, Sonoma mountain Village, available from: http://www.oneplanetcommunities.org/communities/so noma-mountain-village/, accessed, August 18, 2013.

[52].ARUP, Dongtan Eco-City Shanghai, available from: http://www.arup.com/_assets/_download/8CFDEE1ACC3E-EA1A-25FD80B2315B50FD.pdf, accessed April 30, 2013.

[53].Tianjin Eco-city, Sino Singapore Tianjin Eco-city, available from: http://www.tianjinecocity.gov.sg/, accessed August 18, 2013.

[54].Sondgo IBD. Sondgo Eco-city, available from: http://www.songdo.com/Default.aspx, accessed August $18,2013$.

[55].T. Mezher, S. Tabbara, and N. Al Hosany, "An Overview of CSR in the Renewable Energy Sector: Examples from Masdar Initiative in Abu Dhabi." Management of Environmental Quality 21:6:744 - 760, 2010.

[56].T. Mezher, "Building future sustainable cities: the need for a new mindset." Construction Innovation 11:2:136$141,2011$. 